DOI: https://doi.org/10.24127/ajpm.v9i4.3159

\title{
MELEJITKAN JIWA KEWIRAUSAHAAN DAN PRESTASI BELAJAR MELALUI PEMBELAJARAN MATEMATIKA BERBASIS HIGHER ORDER THINKING SKILLS (HOTS)
}

\author{
Muhyani $^{1 *}$, Iis Durotun Nafisah ${ }^{2}$, Sutisna $^{3}$ \\ $1^{*, 2,3}$ Universitas Ibn Khaldun Bogor, Bogor, Indonesia \\ * Corresponding author. Jl. K.H. Sholeh Iskandar Km. 2, 16162, Bogor, Indonesia \\ E-mail: $\quad$ muhyani@fai.uika-bogor.ac.id $^{\left.1^{*}\right)}$ \\ iisduroh12@gmail.com $^{2)}$ \\ stn.sutisna@gmail.com $^{3}$
}

Received 14 October 2020; Received in revised form 05 December 2020; Accepted 14 December 2020

\begin{abstract}
Abstrak
Penelitian ini bertujuan untuk mengetahui peningkatan jiwa kewirausahaan dan prestasi belajar siswa melalui pembelajaran matematika berbasis HOTS. Penelitian ini merupakan penelitian kuantitatif dengan desain penelitian adalah quasi experimental design jenis nonequivalent control group design. Subjek penelitian adalah 34 siswa kelas 3 di MI Mathlaul Anwar tahun Pelajaran 2019-2020. Instrument penelitian berupa tabel observasi dan tes yang diberikan sebelum dan sesudah kegiatan pembelajaran. Pada kelas eksperimen kegiatan pembelajaran matematika berbasis HOTS, sedang pada kelas kontrol kegiatan pembelajaran matematika konvensional. Hasil analisis uji Independent Samples T-Test pada nilai posttest jiwa kewirausahaan kelompok eksperimen dengan kelompok kontrol menunjukkan adanya peningkatan jiwa kewirausahaan siswa dengan menggunakan pembelajaran matematika berbasis HOTS bahkan peningkatannya lebih dari $200 \%$. Demikian juga prestasi belajar siswa melaui uji Independent Samples TTest pada nilai posttest kelompok eksperimen dengan kelompok kontrol menunjukkan adanya peningkatan prestasi belajar siswa dengan menggunakan pembelajaran matematika berbasis HOTS. Berdasarkan analisis data, dapat disimpulkan bahwa pembelajaran matematika berbasis Higher Order Thingking Skills (HOTS) mampu melejitkan jiwa kewirausahaan dan prestasi belajar siswa.
\end{abstract}

Kata Kunci: higher order thinking skills (HOTS); jiwa kewirausahaan; prestasi belajar

\begin{abstract}
This study aims to determine the increase in entrepreneurial spirit and student achievement through HOTSbased mathematics learning. This research is a quantitative research design with a quasi experimental design type nonequivalent control group design. The research subjects were 34 grade 3 students at MI Mathlaul Anwar for the 2019-2020 academic year. Research instruments in the form of observation tables and tests given before and after learning activities. In the experimental class HOTS-based mathematics learning activities, while in the control class conventional mathematics learning activities. The results of the analysis of the Independent Samples T-Test on the posttest scores of the entrepreneurial spirit of the experimental group with the control group showed an increase in the entrepreneurial spirit of students using HOTS-based mathematics learning even the increase was more than 200\%. Likewise, student learning achievement through the Independent Samples T-Test on the posttest scores of the experimental group with the control group showed an increase in student achievement using HOTS-based mathematics learning. Based on data analysis, it can be concluded that Mathematics learning based on Higher Order Thingking Skills (HOTS) is able to boost entrepreneurial spirit and student learning achievement.
\end{abstract}

Keywords: entrepreneurship; higher order thinking skills (HOTS); learning achievement

This is an open access article under the Creative Commons Attribution 4.0 International License 
DOI: https://doi.org/10.24127/ajpm.v9i4.3159

\section{PENDAHULUAN}

Tradisi dalam lingkungan pendidikan Islam baik di madrasah maupun pesantren, sejak awal berdirinya oraganisasi Islam yang dipelopori oleh Syarikat Islam adalah untuk meningkatkan peran ekonomi dan pendidikan ummat (Makarao \& Zoelva, 2018). Namun cita-cita para pendiri bangsa kini belum membuahkan hasil. Salah satu penyebabnya adalah karena sebagian besar penduduknya hanya menjadi pekerja, jarang sekali yang menjadi pelaku wirausaha (Hidayah, 2016). Bila dibandingkan dengan negara tetangga seperti Malaysia dan Singapura, jumlah persentase penduduk Indonesia yang menjadi pengusaha masih jauh di bawah kedua negara jiran tersebut (Siregar, 2020). Salah satu penyebab rendahnya minat anak Indonesia menjadi pengusaha adalah pembelajaran di sekolah hanya mengajarkan materinya saja tanpa mengaitkan dengan yang lain (Muhyani, 2012).

Selain rendahnya minat menjadi pengusaha, prestasi siswa Indonesia menurut Trends in Mathematic and Science Study (TIMSS) juga rendah, untuk matematika menempati peringkat 45 dari 50 negara yang disurvey dan sains (IPA) nomor 45 dari 48 negara yang disurvey(Arifuddin, 2020)(Gronmo, Lindquist, Arora, \& Mullis, 2016). The Organisation of Economi Co-operation and Development (OECD) mengumumkan Programme for Internasional Student Assesment (PISA), skor Indonesia cenderung turun. Bahkan untuk matematika $71 \%$ siswa berada di bawah kompetensi minimal (Megawati, Wardani, \& Hartatiana, 2020)(OECD, 2019).

Matematika adalah bidang studi yang sangat penting dan merupakan ilmu yang digunakan oleh semua disiplin ilmu, serta mampu mengembangkan daya pikir manusia untuk memecahkan masalah (Juwaeriah, Muhyani, \& Ikhtiono, 2017). Bahkan matematika adalah modal bagi tiap individu untuk berkiprah di era informasi (Muhyani \& Dahlia, 2015). Matematika yang demikian pentingnya, akibat kegiatan pembelajaran diberikan dengan pendekatan konvensional (ceramah) oleh sebagian besar guru di Indonesia menjadi membosankan dan menyebalkan (Azqia, Muhyani, \& Yono, 2019). Sehingga matematika bagi sebagian besar siswa di Indonesia dianggap musuh yang menakutkan yang ingin sekali mereka hindari (Juwaeriah et al., 2017). Tidak sedikit siswa yang mengeluh dengan adanya pelajaran matematika (Hadi, 2019). Hal ini yang kemudian memicu prestasi belajar matematika masih sangat rendah(Putri \& Widodo, 2018). Pandangan tentang materi matematika yang rumit dan sulit semakin membuat para siswa malas mempelajarinya(Aprilia \& Royanto, 2020) (Yunitasari, 2018). Berdasarkan laporan hasil UNBK tahun 2019 nilai rerata matematika paling rendah dari semua bidang studi yang diujikan. Dan bila dibandingkan nilai rerata matematika MTs lebih rendah dibanding SMP. Hasil ini menunjukkan bahwa rerata kemampuan matematika siswa Madrasah masih di bawah SD/SMP/SMA (Puspendik, 2019). Salah satu faktor utama yang sangat berpengaruh dalam keberhasilan pembelajaran adalah keberadaan guru, terutama dalam penerapan metode yang tepat dala $\mathrm{m}$ pembelajaran (Syafi'i, A., M , Tri, 2018).

Berdasarkan observasi dan wawancara terhadap guru MI Mathlaul Anwar Kec. Leuwiliang Kabupaten Bogor dan guru MI di tempat lain, kegiatan pembelajaran yang mereka 
lakukan hanya menggunakan metode konvensional (ceramah) dengan mengikuti pedoman pada buku paket (Buku Matematika) yang mereka miliki. Bahkan menurut Ichsan (2019) sebagian besar institusi sekolah pada semua level, pembelajaran masih menggunakan model pembelajaran konvensional (Ichsan, Sigit, \& Miaesyah, 2019). Kondisi ini mengakibatkan peserta didik mengalami kendala ketika menghadapi masalah kontekstual yang menuntut kemampuan menganalisa, menilai, dan mencipta (Khotimah \& Sari, 2020), sehingga prestasi belajarnya rendah dan tidak mampu memecahkan masalah yang dihadapi dengan kreatif.

Rendahnya prestasi belajar siswa dan sedikitnya jumlah pelaku wirausaha berpengaruh terhadap banyaknya pengangguran. Salah satu upaya untuk mengatasi pengangguran adalah mendorong tumbuhnya wira usaha baru. Untuk menjadi seorang pengusaha dibutuhkan kemampuan dasar, kemampuan menjalin kerja sama dengan orang lain, dan kemampuan konseptual. Dan salah satu kemampuan dasar yang wajib dimiliki adalah kemampuan dalam bidang matematika(Supriatna, 2017). Menurut Survei Tenaga Kerja Nasional (Sakernas), tingkat pengangguran di Indonesia termasuk tinggi. Kondisi ini merupakan masalah serius dalam hal ketenagakerjaan, apalagi tiap tahun jumlah pengangguran terdidik lulusan perguruan tinggi juga terus bertambah, sementara masih terbatasnya lowongan kerja. Untuk itu, diperlukan suatu upaya agar pendidikan di sekolah mampu menghasilkan lulusan yang memiliki keterampilan dan keahlian yang dibutuhkan oleh dinamika dunia usaha (Maryati, 2015), salah satunya adalah penerapan pembelajarn berbasis HOTS. Banyaknya jumlah pengangguran merupakan bukti dari rendahnya penerapan pembelajaran yang mengasah keterampilan berpikir tingkat tinggi siswa. Siswa yang mempunyai keterampilan tingkat tinggi akan mampu memecahkan masalah, karena itu siswa zaman milenial harus memiliki kemampuan untuk menyelesaikan masalah yang makin kompleks (Annisah, 2018). Selain itu sikap percaya diri dan kemampuan berpikir kritis sebagai salah satu indikator jiwa kewirausahaan dapat meningkat melalui pembelajaran Problem Based Learning (PBL) terintegrasi HOTS (Rezkillah \& Haryanto, 2020) (Suhirman, Yusuf, Muliadi, \& Prayodi, 2020).

Berdasarkan latar belakang masalah tersebut, perlu adanya upaya untuk melejitkan prestasi dan jiwa kewirausahaan, salah satunya adalah dengan penerapan pembelajaran berbasis HOTS. Menggunakan pembelajaran berbasis HOTS mampu menghasilkan capaian belajar yang cukup efektif (Fanani \& Kusmaharti, 2014). HOTS adalah keterampilan berpikir yang lebih dari pada sekedar menghafalkan fakta atau konsep, HOTS mengharuskan siswa melakukan sesuatu atas fakta-fakta tersebut (Riadi, 2016). Siswa harus memahami, menganalisis satu sama lain, mengkategorikan, memanipulasi, menciptakan cara-cara baru secara kreatif, dan menerapkannya dalam mencari solusi terhadap persoalanpersoalan baru (Hasyim, Maylita; Kusuma, 2019). HOTS adalah keterampilan berfikir tingkat tinggi yang menuntut pemikiran secara kritis, kreatif, analitis, terhadap informasi dan data dalam memecahkan permasalahan (Fanani \& Kusmaharti, 2014). Diantara model-model pembelajaran yang berbasis HOTS adalah pembelajaran berbasis masalah (Sastrawati, Rusdi, \& Syamsurizal., 2011) dan pembelajaran kontekstual yang dapat membantu guru 
menanamkan konsep yang dipelajari melalui aktivitas yang menyerupai kehidupan nyata (Khusniati, 2012).

Pendidikan generasi melenial harus melahirkan SDM unggul yang berpikir kritis, kreatif, logis, sistematis, dan mampu bekerja dalam team (Kurniati, Harimukt, \& Jamil, 2016). Pendidikan akan menghasilkan generasi unggul dan lebih berhasil bila dibekali dengan keterampilan berpikir tingkat tinggi (HOTS) (Tanujaya, Mumu, \& Margono, 2017). Dengan kemampuan berpikir tingkat tinggi, siswa dapat mengimplementasikan kemampuan kritis dan kreatifnya untuk memecahkan masalah dalam kehidupan sehari-hari (Hidayati \& Retnawati, 2018). Sehingga ia tidak menunggu lowongan lapangan kerja, namun mampu membaca peluang, salah satunya yaitu dengan berwirausaha. Maka dari itu dalam suatu pembelajaran sangat penting menerapkan pembelajaran matematika berbasis HOTS, selain mampu meningkatkan prestasi belajar juga diharapkan mampu meningkatkan jiwa kewirausahaan siswa sehingga tercapainya SDM yang kreatif dan berkualitas.

Berdasarkan latar belakang di tersebut, penelitian yang dilakukan bertujuan untuk mengetahui pengaruh pembelajaran berbasis HOTS terhadap prestasi belajar dan jiwa kewirausahaan siswa pada mata pelajaran matematika. Sehingga dapat membedakan hasil dari pembelajaran berbasis HOTS dengan pembelajaran yang hanya menggunakan metode ceramah atau konvensional.

\section{METODE PENELITIAN}

Penelitian ini merupakan penelitian eksperimen, namun karena tidak memungkinkan mengontrol variabel lain yang mempengaruhi, maka penelitian ini dikategorikan ekperiman semu. Jenis penelitian ini adalah penelitian kuantitatif, maka dari itu semua gejala yang diamati diukur dalam bentuk angka, sehingga memungkinkan adanya penggunaan teknik analisis statistik (Muhyani, 2019). Desain pada penelitian ini adalah quasi experimental design jenis nonequivalent control group design. Sehingga dalam desain ini pemilihan subjek tidak diacak atau random namun sengaja dipilih. Adapun desain penelitian tergambar pada Tabel 1.

Tabel 1. Desain penelitian.

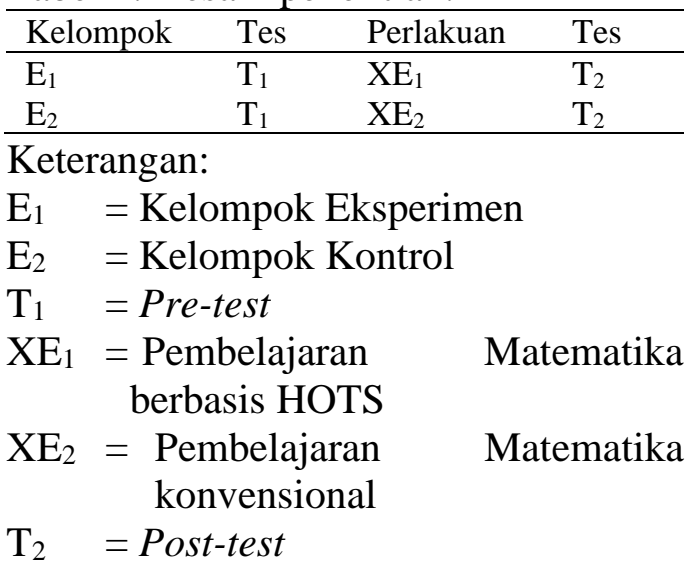

Penelitian ini dilakukan di MI Mathlaul Anwar Geledug Kecamatan Leuwiliang Kabupaten Bogor. Subjek dalam penelitian ini adalah kelas 3 dengan jumlah 34 siswa. Kemudian dari jumlah siswa tersebut dibuat 2 kelompok yaitu kelompok eksperimen dan kelompok kontrol. Setiap kelompok masing-masing berjumlah 17 siswa. Penelitian dilakukan 3 tahap, pertama tahap pra eksperimen adalah tahap menentukan kelompok eksperimen dan kelompok kontrol. Kelompok eksperimen menjadi kelompok yang mendapat treatment (perlakuan) sedangkan kelompok kontrol tidak diberi treatment (perlakuan). Namun kedua kelompok ini diberikan pretest (tes awal) untuk mengetahui keadaan kedua kelas tersebut. Kedua, tahap eksperimen 
adalah memberikan perlakuan yang berbeda, yaitu kelompok eksperimen dilakukan pembelajaran matematika berbasis HOTS sedangkan kelas kontrol dilakukan pembelajaran matematika dengan menggunakan pendekatan pembelajaran metode ceramah atau konvensional. Ketiga, tahap pasca eksperimen yaitu kedua kelompok tersebut diberikan posttest (tes akhir) yang untuk mengetahui seberapa besar pengaruh dari perlakuan yang telah dilakukan. Hasil posttest dibandingkan dengan hasil yang didapatkan pada saat pretest.

Pada kelompok eksperimen dan kelompok kontrol sebelum kegiatan pembelajaran dimulai siswa diberikan pretest terlebih dahulu. Tujuannya agar dapat diketahui kondisi awal prestasi belajar siswa sebelum mendapatkan kegiatan pembelajaran. Kegiatan pembelajaran pada kelas eksperimen siswa belajar materi mengenai uang dengan pembelajaran matematika berbasis HOTS. Aktivitas siswa melakukan simulasi jual beli. Dalam simulasi jual beli, selain siswa dapat mengenal mata uang, juga melakukan operasi penjumlahan dan pengurangan, bahkan mengelola uang tersebut. Walaupun pada prosesnya hanya menggunakan uang mainan, namun siswa mempraktikannya seperti dalam kehidupan sehari-hari. Sedangkan pada kelompok kontrol siswa belajar materi tentang uang juga, namun kegiatan pembelajarannya menggunakan pembelajaran konvensional atau ceramah. Langkah awal guru menjelaskan materi pelajaran dengan menjelaskan tentang uang memberikan contoh soal. Sedangkan siswa hanya memperhatikan pemaparan guru. Setelah kegiatan pembelajaran selesai baik di kelompok eksperimen maupun kelompok kontrol siswa mengerjakan soal posttest. Hal ini agar dapat diketahui kondisi siswa setelah mengikuti kegiatan pembelajaran.

Penelitian ini bertujuan untuk membandingkan jiwa kewirausahaan dan prestasi belajar siswa pada kelompok eksperimen yang menggunakan pembelajaran matematika berbasis HOTS dengan siswa pada kelompok kontrol yang menggunakan pendekatan pembelajaran konvensional. Teknik Pengumpulan data dalam penelitian ini menggunakan dua instrumen. Instrumen yang pertama tes berupa soal pilihan ganda untuk mengetahui prestasi belajar siswa dan yang kedua non tes berupa tabel observasi untuk mengetahui jiwa kewirausahaan siswa. Indikator jiwa kewirausahaan yang diamati adalah adanya sikap percaya diri, berani mengambil resiko, cekatan, adanya jiwa kepemimpinan, apa adanya, dan berorientasi pada masa depan (Haji, Abdullah, Ilham, \& Yumiati, 2017). Untuk mendapatkan data tentang jiwa kewirausahaan menggunakan tabel pengamatan yang berasal dari respon siswa atas pertanyaan tentang indikator karakter jiwa kewirausahaan.

Instrumen tes berupa soal pilihan ganda, tiap butir soal telah dilakukan uji validitas dan uji reliabilitas. Uji validitas dan uji reliabilitas diberikan kepada 15 responden di MI Al-Islamiyah dengan 35 butir soal. Dari 35 butir yang diujicoba setelah divalidasi, ada 15 butir soal valid dan reliabel. Butir yang valid dan reliabel inilah yag digunakan untuk pengambilan data. Instrumen ini diberikan kepada siswa untuk memberikan jawaban atas pertanyaan yang diberikan. Pemberian istrumen penelitian dilakukan dua kali yaitu pretest diberikan sebelum perlakuan dan posttest diberikan setelah perlakuan. 
DOI: https://doi.org/10.24127/ajpm.v9i4.3159

Data yang diperoleh dari pretest dan posttest yang berasal kelompok eksperimen dan kelompok kontrol, baik yang berasal dari tes prestasi dan non-tes tentang jiwa kewirausahaan ditabulasikan dalam skala $0-100$. Cara ini digunakan untuk mempermudah dalam analisis data. Analisis statistik atas data hasil penelitian menggunakan analisis deskriptif dan analisis inferensial. Analisis deskriptif digunakan untuk mengetahui data hasil penelitian, analisis inferensial digunakan untuk mengetahui berpengaruh tidaknya data hasil penelitian menggunakan uji t. Bila data berdistribusi normal dan homogen uji $\mathrm{t}$ menggunakan statistik parametrik, namun bila tidak maka menggunakan statistik non parametrik. Karena itu sebelum dianalisis data diuji untuk mengetahui normalitas dan homogenitas. Pengujian normalitas menggunakan uji Shapiro Wilk untuk mengetahui data yang ditest berdistribusi normal atau tidak. Sementara uji homogenitas dilakukan untuk mengetahui kedua data memiliki varians homogen atau tidak. Pengujian dilakukan untuk menjawab hipotesis penelitian yang diajukan. Semua pengujian dibantu dengan aplikasi Statistical Product and Service Solutions 24 (SPSS 24).

\section{HASIL DAN PEMBAHASAN}

Hasil pretest dan posttest baik kelompok eksperimen maupun kelompok kontrol subyek penelitian tercantum pada Tabel 2.

Tabel 2. Statistik deskriptif subyek penelitian.

\begin{tabular}{lllllllll}
\hline \multirow{2}{*}{ Statistik } & \multicolumn{3}{c}{ Kel. Eksperimen } & \multicolumn{3}{c}{ Kel. Kontrol } \\
\cline { 2 - 9 } & \multicolumn{2}{c}{$\begin{array}{c}\text { Nilai } \\
\text { Matematika }\end{array}$} & \multicolumn{2}{c}{$\begin{array}{c}\text { Jiwa } \\
\text { Kewirausahaan }\end{array}$} & \multicolumn{2}{c}{$\begin{array}{c}\text { Nilai } \\
\text { Matematika }\end{array}$} & \multicolumn{2}{c}{ Kewiwa } \\
& yretest & posttest & pretest & posttest & pretest & posttest & pretest & posttest \\
\hline $\mathrm{n}$ & 17 & 17 & 17 & 17 & 17 & 17 & 17 & 17 \\
$\mathrm{X}_{\max }$ & 93 & 100 & 60 & 95 & 73 & 87 & 45 & 60 \\
$\mathrm{X}_{\min }$ & 20 & 73 & 25 & 50 & 20 & 20 & 20 & 35 \\
Range & 73 & 27 & 35 & 45 & 53 & 57 & 25 & 25 \\
Mean & 56,29 & 84,41 & 36,76 & 77,06 & 53,64 & 64,76 & 30,88 & 42,65 \\
SD & 20,3 & 8,3 & 11,31 & 11,33 & 14,1 & 15,0 & 6,43 & 7,31 \\
\hline
\end{tabular}

Tabel 2 menggambarkan prestasi belajar siswa kelompok eksperimen, nilai rerata pretest adalah 56,29 dan posttest 85,41. Nilai tersebut menunjukkan adanya peningkatan ratarata prestasi belajar pada kelompok eksperimen. Sedangkan pada kelompok kontrol, nilai rata-rata pretest adalah 53,64 dan posttest 64,76. Nilai tersebut menunjukkan peningkatan rata-rata nilai prestasi belajar pada kelompok kontrol. Dari kedua data tersebut dapat diketahui bahwa kedua kelompok mengalami peningkatan prestasi belajar. Namun, peningkatan pada kelompok eksperimen lebih besar dari kelompok kontrol.

Berdasarkan data pada Tabel 2, jiwa kewirausahaan siswa kelompok eksperimen rerata skor hasil observasi awal adalah 36,76 dan hasil observasi setelah perlakuan adalah 77,06. Skor tersebut menunjukkan adanya peningkatan jiwa kewirausahaan siswa pada kelompok eksperimen. Sedangkan kelompok kontrol rata-rata skor pretest adalah 30,66 dan posttest sebesar 42,62. Skor tersebut menunjukkan adanya peningkatan rerata jiwa kewirausahan pada kelompok kontrol. Dari kedua data 
tersebut dapat diketahui bahwa kedua kelompok mengalami peningkatan jiwa kewirausahaan. Namun, peningkatan pada kelompok eksperimen lebih besar dari kelompok kontrol.

Analisis deskriptif untuk kelompok eksperimen selisih rata-rata untuk prestasi belajar adalah 29,12, sedangkan selisih skor rata-rata prestasi belajar kelompok kontrol adalah 11,12. Peningkatan prestasi belajar pada kelompok eksperimen jauh lebih tinggi bila dibandingkan peningkatan pada kelompok kontrol, dengan kata lain pembelajaran matematika berbasis HOTS mampu melejitkan prestasi siswa. Demikian juga dengan jiwa kewirausahaan siswa, pada kelompok eksperimen peningkatan skor adalah 40,3 sedang pada kelompok kontrol peningkatan rata-rata skor adalah 11,77. Hasil ini menunjukkan bahwa pembelajaran matematika berbasis HOTS mampu melejitkan jiwa kewirausahaan siswa.

\section{Uji Normalitas}

Uji normalitas bertujuan untuk mengetahui apakah distribusi sebuah data mengikuti atau mendekati distribusi normal atau tidak. Hasil uji ini digunakan untuk menentukan jenis statistic parametrik atau non parametrik yang akan digunakan ketika uji hipotesis. Hasil uji normalitas disajikan pada Tabel 3.

Tabel 3. Hasil uji normalitas prestasi belajar dan jiwa kewirausahaan kelompok eksperimen dan kelompok kontrol

\begin{tabular}{lrrrrrrrr}
\hline & \multicolumn{9}{c}{ Tests of Normality } \\
\hline Shapiro- & \multicolumn{3}{c}{ Kelompok Eksperimen } & \multicolumn{3}{c}{ Kelompok Kontrol } \\
\cline { 2 - 9 } Wilk & \multicolumn{2}{c}{ Prestasi } & \multicolumn{1}{c}{ Kewirausahaan } & \multicolumn{2}{c}{ Prestasi } & \multicolumn{1}{c}{ Kewirausahaan } \\
\cline { 2 - 9 } & Pre test & Posttest & Pre test & Posttest & Pre test & Posttest & Pre test & Posttest \\
\hline Statistic & .974 & .913 & .783 & .939 & .862 & .782 & .930 & .870 \\
df & 17 & 17 & 17 & 17 & 17 & 17 & 17 & 17 \\
Sig. & .885 & .113 & .001 & .306 & 017 & .001 & .220 & 022 \\
\hline
\end{tabular}

Berdasarkan hasil analisis normalitas pada Tabel 3 dengan menggunakan Test of Normality dengan uji Shapiro-Wilk pada nilai prestest dan posttest prestasi belajar kelompok eksperimen dan kelompok kontrol, diperoleh hasil signifikansi data dengan $\mathrm{df}=17$. Pengambilan keputusan dengan melihat hasil signifikansi data, apabila hasil Sig. lebih besar dari 0,05 maka dapat dinyatakan bahwa data yang diperoleh dari kelompok eksperimen dan kelompok kontrol berdistribusi normal. Uji Homogenitas

Uji homogenitas dilakukan untuk mengetahui bahwa dua atau lebih kelompok data sampel berasal dari populasi yang memiliki variansi yang sama. Hasil uji homogenitas dapat dilihat pada Tabel 4.

Berdasarkan hasil perhitungan pada Tabel 4 dengan menggunakan Test of Homogeneity diperoleh nilai Sig. Based on Mean prestasi belajar 0,283, dan jiwa kewirausahaan 0,134 , nilai. lebih besar dari 0,05 maka dapat dinyatakan bahwa data yang diperoleh dari kelompok eksperimen dan kelompok kontrol adalah homogen atau sama. Dengan demikian, telah terpenuhi salah satu syarat dari uji independent test. 
DOI: https://doi.org/10.24127/ajpm.v9i4.3159

Tabel 4. Hasil uji homogenitas prestasi belajar dan jiwa kewirausahaan kelompok eksperimen dan kelompok kontrol.

\begin{tabular}{|c|c|c|c|c|c|}
\hline \multicolumn{6}{|c|}{ Test of Homogeneity of Variance } \\
\hline & Based on & Levene Statistic & $d f 1$ & $d f 2$ & Sig. \\
\hline Prestasi & Mean & 1.194 & 1 & 32 & .283 \\
\hline \multirow[t]{4}{*}{ Belajar } & Median & 472 & 1 & 32 & .497 \\
\hline & Median and with adj $d f$ & .472 & 1 & 21.065 & .500 \\
\hline & trimmed mean & .650 & 1 & 32 & .426 \\
\hline & Mean & 2.366 & 1 & 32 & .134 \\
\hline & Median & 1.525 & 1 & 32 & .226 \\
\hline \multirow{2}{*}{ Kewirausahaan } & Median and with adjusted df & 1.525 & 1 & 27.179 & .227 \\
\hline & trimmed mean & 2.527 & 1 & 32 & .122 \\
\hline
\end{tabular}

\section{Hasil Uji $t$}

Berdasarkan analisis deskriptif data penelitian, prestasi belajar siswa pada kelompok eksperimen dan kelompok kontrol terdapat perbedaan rata-rata. Untuk kelompok eksperimen nilai rata-rata pretest adalah 56,29 dan posttest sebesar 85,41. Sedangkan pada kelompok kontrol mendapatkan nilai rata-rata pretest 53,64 dan posttest 64,76. Menurut analisis deskriptif terdapat perbedaan yang signifikan dari kedua kelompok tersebut. Dimana pada kelompok eksperimen peningkatan prestasi belajar siswa jauh lebih besar dibanding kelompok kontrol. Untuk menjawab hipotesis penelitian apakah model pembelajaran matematika berbasis Higher Order Thinking Skill mampu melejitkan prestasi belajar matematika, perlu dibuktikan dengan analisis inferinsial berupa uji t (t-test) dengan menggunakan piranti SPSS 24. adapun hasil analisis dapat dilihat pada Tabel 5.

Tabel 5. Hasil uji independent sampel t-test terhadap prestasi belajar siswa

\begin{tabular}{|c|c|c|c|c|c|c|c|c|c|}
\hline \multicolumn{10}{|c|}{ Independent Samples Test } \\
\hline & & \multicolumn{2}{|c|}{$\begin{array}{l}\text { Levene's Test } \\
\text { for Eq.of Var } \\
\end{array}$} & \multicolumn{6}{|c|}{ t-test for Equality of Means } \\
\hline & & \multirow{2}{*}{$\boldsymbol{F}$} & \multirow{2}{*}{ Sig. } & \multirow[t]{2}{*}{$t$} & \multirow{2}{*}{$\begin{array}{l}\text { Sig. }(2- \\
\text { tailed })\end{array}$} & \multirow{2}{*}{$\begin{array}{l}\text { Mean } \\
\text { Diff. }\end{array}$} & \multirow{2}{*}{$\begin{array}{l}\text { Std. Err. } \\
\text { Diff. }\end{array}$} & \multicolumn{2}{|c|}{$\begin{array}{c}\text { 95\% Conf.Interval of } \\
\text { the Difference }\end{array}$} \\
\hline & & & & & & & & Lower & Upper \\
\hline \multirow{2}{*}{$\begin{array}{c}\text { Hasil } \\
\text { Prestasi } \\
\text { Belajar }\end{array}$} & $\begin{array}{l}\text { Equal var } \\
\text { assumed }\end{array}$ & 1.194 & .283 & 4.978 & .000 & 206.471 & 41.476 & 121.986 & 290.955 \\
\hline & $\begin{array}{c}\text { Equal } \\
\text { var.not ass. }\end{array}$ & & & 4.978 & .000 & 206.471 & 41.476 & 121.031 & 291.910 \\
\hline
\end{tabular}

Berdasarkan hasil analisis data pada Tabel 5 dengan uji Independent Samples T-Test pada nilai posttest kelompok eksperimen dengan kelompok kontrol Hasil t hitung adalah 4,978 dengan jumlah seluruh siswa yaitu 34 dan df $=32$. Pengambilan keputusan berdasarkan hasil sig.(2-tailed) adalah 0,000 . Hasil ini menunjukkan 0,000 .
Hipotesisnya dirumuskan sebagai berikut:

$\mathrm{H}_{0}$ : Bila Sig.(2-tailed) > 0,05, tidak terdapat peningkatan prestasi belajar.pada kelompok eksperimen.

Ha: Bila Sig.(2-tailed) < 0,05, terdapat peningkatan prestasi belajar pada kelompok eksperimen. 
DOI: https://doi.org/10.24127/ajpm.v9i4.3159

Karena nilai Sig. (2-tailed) 0,00 lebih kecil dari 0,05 , maka $\mathrm{H}_{0}$ ditolak dan Ha diterima. Kondisi ini menunjukkan bahwa terdapat peningkatan prestasi yang signifikan antara nilai rata-rata posttest kelompok eksperimen dengan kelompok kontrol. Dengan kata lain terdapat peningkatan prestasi belajar siswa dengan menggunakan pembelajaran matematika berbasis HOTS.

Berdasarkan analisis deskriptif jiwa kewirausahaan siswa kelompok eksperimen rerata nilai posttest mengalami peningkatan sebesar 40,3 dari nilai rerata pretest. Sedangkan untuk kelompok kontrol, jiwa kewirausahaan nilai rerata posttest mengalami peningkatan sebesar 11,77 dari rerata pretest. Dari kedua data tersebut kedua kelompok mengalami peningkatan jiwa kewirausahaan. Namun, peningkatan pada kelompok eksperimen lebih besar dari kelompok kontrol. Untuk lebih akurat dianalisis dengan uji t, yang hasilnya dapat dilihat pada Tabel 6 .

Tabel 6. Hasil independent sampel t-test terhadap jiwa kewirausahaan siswa.

\begin{tabular}{|c|c|c|c|c|c|c|c|c|c|c|}
\hline \multicolumn{11}{|c|}{ Independent Samples Test } \\
\hline & & \multicolumn{3}{|c|}{$\begin{array}{c}\text { Levene's Test for } \\
\text { Equality of } \\
\text { Variances } \\
\end{array}$} & \multicolumn{6}{|c|}{ t-test for Equality of Means } \\
\hline & & \multirow[t]{2}{*}{$F$} & \multirow[t]{2}{*}{ Sig. } & \multirow[t]{2}{*}{ 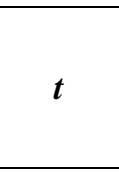 } & \multirow[t]{2}{*}{$d f$} & \multirow{2}{*}{$\begin{array}{l}\text { Sig. }(2- \\
\text { tailed })\end{array}$} & \multirow{2}{*}{$\begin{array}{c}\text { Mean } \\
\text { Diff. }\end{array}$} & \multirow{2}{*}{$\begin{array}{c}\text { Std. } \\
\text { Erro } \\
r \\
\text { Diff. }\end{array}$} & \multicolumn{2}{|c|}{$\begin{array}{l}\text { 95\% Conf Int } \\
\text { of the Diff }\end{array}$} \\
\hline & & & & & & & & & Low & Upp \\
\hline jiwa & $\begin{array}{c}\text { Equal var } \\
\text { assumed }\end{array}$ & 2.366 & .134 & 10.523 & 32 & .000 & 68.824 & .654 & 55.501 & 82.146 \\
\hline kewirausahaan & $\begin{array}{c}\text { Equal var } \\
\text { not ass. }\end{array}$ & & & 10.523 & 27.366 & .000 & 68.824 & .654 & 55.412 & 82.235 \\
\hline
\end{tabular}

Berdasarkan analisis uji $\mathrm{T}$ pada Tabel 6, uji Independent Samples T-Test pada nilai posttest kelompok eksperimen dengan kelompok kontrol diperoleh hasil t hitungnya 10,523 dengan jumlah seluruh siswa yaitu 34 dan $\mathrm{df}=32$. Pengambilan keputusan berdasarkan hasil sig.(2-tailed) adalah 0,000.

Hipotesisnya dirumuskan sebagai berikut:

$\mathrm{H}_{0}$ : Bila Sig.(2-tailed) > 0,05, tidak terdapat peningkatan jiwa kewirausahaan.pada kelompok eksperimen.

Ha: Bila Sig.(2-tailed) $<0,05$, terdapat peningkatan jiwa kewirausahaan pada kelompok eksperimen.

Karena Sig. (2-tailed) 0,00 lebih kecil dari 0,05 maka $\mathrm{H}_{0}$ ditolak atau $\mathrm{Ha}$ diterima. Sehingga dapat dinyatakan bahwa terdapat peningkatan yang signifikan antara nilai rata-rata posttest kelompok eksperimen dengan kelompok kontrol. Dengan kata lain jiwa kewirausahaan siswa meningkat melalui pembelajaran matematika berbasis HOTS.

Hasil penelitian tentang jiwa kewirausahaan siswa kelas 3 di MI Mathlaul Anwar adalah adanya peningkatan jiwa kewirausahaan pada kedua kelompok baik kelompok eksperimen maupun kelompok kontrol. Namun peningkatan pada kelompok eksperimen lebih tinggi dibanding kelompok kontrol, kelompok eksperimen meningkat 209,66\% sedangkan pada kelompok kontrol hanya 140,83\%. Observasi dilakukan selama 3 pertemuan, pada kelompok eksperimen dan pada kelompok kontrol. Pada kelompok kontrol, pertemuan pertama, 
sebelum diberikan pembelajaran konvensional atau ceramah, siswa belum terlihat memiliki jiwa kewirausahaan, hampir semua siswa tidak menunjukkan adanya jiwa kewirausahaan. Selanjutnya pada pertemuan kedua terdapat beberapa siswa yang mulai menunjukkan jiwa kewirausahaan. Pada pertemuan ketiga, setelah diberikan pembelajaran dengan metode ceramah, sekitar kurang lebih $50 \%$ yang mulai menunjukkan jiwa kewirausahaanya. Sedangkan pada kelas eksperimen, pada pertemuan pertama, sebelum diberikan pembelajaran berbasis HOTS, siswa belum terlihat memiliki jiwa kewirausahaan. Pada pertemuan kedua beberapa siswa mulai menunjukkan peningkatan jiwa kewirausahaan. Setalah itu, pada pertemuan ketiga sebagian besar siswa mulai mengalami peningkatan jiwa kewirausahaan.

Melejitnya jiwa kewirausahaan dan prestasi belajar siswa pada kelompok eksperimen disebabkan oleh suasana kegiatan pembelajaran yang menyenangkan. Kondisi ini mampu meningkatkan minat belajar siswa, dengan minat belajar yang tinggi siswa lebih aktif dan besungguh-sungguh dalam kegiatan belajar. Selain itu Pembelajaran model ini memberi kesempatan pada siswa untuk berdiskusi, bertukar pengetahuan, belajar dari teman, bekerja sama dalam memecahkan masalah, dan memaparkan solusi yang ditemukan (Darhim, Prabawanto, \& Susilo, 2020) Akibatnya capaian dalam sikap (jiwa kewirausahaan) dan prestasi belajar meningkat. Kelebihan model pembelajaran pada kelompok kontrol (PBL) adalah mampu menumbuhkan minat belajar siswa. Dibanding dengan pembelajaran konvensional model belajar ini jauh lebih baik. Salah satu kekurangan model belajar ini adalah ketidaksiapan guru untuk menerapkan- nya, karena dibutuhkan kepiawaian guru dan perlu dukungan sarana yang memadai. Penerapan pembelajaran model ini bagi siswa mampu meningkatkan minat belajar, dan kualitas pembelajaran akan meningkat sehingga penguasaan IPTEK siswa juga akan meningkat. Selain itu siswa akan lebih siap dalam memecahkan maslah yang dihadapi dalam kehidupan sehari-hari.

Hasil penelitian menggambarkan

bahwa pembelajaran matematika berbasis HOTS mampu melejitkan jiwa kewirausahaan dan prestasi belajar siswa. Ini disebabkan karena siswa merasa tertantang untuk lebih aktif dalam mengikuti kegiatan pembelajaran. Aktifnya siswa dalam kegiatan pembelajaran mampu meningkatkan prestasi dan minat siswa (Sutrisno, Happy, \& Susanti, 2020). Hasil penelitian ini sejalan dengan hasil penelitian Tanujaya (2017) yang menyimpulkan bahwa pembelajaran berbasis HOTS mampu meningkatkan jiwa kewirausahaan dan prestasi belajar siswa (Tanujaya et al., 2017; Ramos, Dolipas, \& Villamor, 2013; Fariyani, Rusilowati, \& Sugianto, 2017).

\section{KESIMPULAN DAN SARAN}

Berdasarkan hasil penelitian dan analisis data yang telah dilakukan maka dapat disimpulkan bahwa pembelajaran matematika berbasis HOTS dapat melejitkan jiwa kewirausahaan dan prestasi siswa. Dengan kata lain pembelajaran matematika berbasis HOTS lebih baik dibanding pembelajaran matematika konvensional. Sebagai tindak lanjut dari penelitian ini, disarankan pada para guru untuk meninggalkan pembelajaran dengan konvensional, untuk materi aritmatika sosial bisa menggunakan model pembelajaran berbasis HOTS, salah satunya dengan praktek jual beli (market day). Penerapan pembelajaran model ini 
mampu melejitkan jiwa kewirausahaan dan meningkatkan prestasi siswa. Sejatinya bermain 'jualan' sudah menjadi kebiasaan anak-anak masa prasekolah, ada yang berperan sebagai pedagang dan ada yang berperan sebagai pembeli. Jangan sampai bakat menjadi pengusaha anak Indonesia hilang karena penerapan model pembelajaran di sekolah tidak memupuk tumbuhnya jiwa kewirausahaan siswa. Ingat sebuah Hadits Nabi SAW menyatakan bahwa 9 sembilan dari 10 pintu rizki ada pada perniagaan. Untuk penelitian selanjutnya disarankan untuk melakukan penelitian serupa di tempat lain, mengingat penelitian ini dilakukan pada masa pendemi sehingga banyak keterbatasan, baik subyek penelitian, maupun waktu tatap muka yang terbatas.

\section{DAFTAR PUSTAKA}

Annisah, S. (2018). Pengembangan Bahan Ajar Matematika Materi Geometri untuk Meningkatkan Kemampuan Pemecahan Masalah Mahasiswa PGMI IAIN Metro. $A l$ Ibtida: Jurnal Pendidikan Guru MI, 5(1), 39-52. https://doi.org/https://doi.org/10.24 235/al.ibtida.snj.v5i1.2491

Aprilia, R., \& Royanto, L. R. (2020). Doesn metacognition matter in the relationship between mathematics interest and mathematics anxiety? Ilkogretim Online-Elementary Education Online, 19(4), 23962406.

https://doi.org/10.17051/ilkonline. 2020.764414

Arifuddin, A. (2020). Analisis Keterampilan Berpikir Kritis Calon Guru Sekolah Dasar dalam Menyelesaikan Masalah Matematika. Al Ibtida: Jurnal Pendidikan Guru MI, 7(1), 46-55. Retrieved from http://www.syekhnurjati.ac.id/jurn al/index.php/ibtida/article/view/62 12

Azqia, E. A., Muhyani, \& Yono. (2019). Pengaruh Pendekatan Matematika Realistik Terhadap Prestasi Dan Karakter Mandiri Siswa Kelas 3 DI SD IT AL-MADINAH. EDUMAT: Jurnal Pendidikan Matematika, 7(1), $34-40$. https://doi.org/DOI:10.20527/edum at .v7i1.6095

Darhim, Prabawanto, S., \& Susilo, B. E. (2020). The Effect of Problembased Learning and Mathematical Problem Posing in Improving Student's Critical Thinking Skills. Imternational Journal of Intruction, 13(4), 104-116. https://doi.org/. https://doi.org/10.29333/iji.2020.1 $347 \mathrm{a}$

Fanani, A., \& Kusmaharti. (2014). Pengembangan pembelajaran berbasis HOTS (Higher Order Thinking Skill) di Sekolah Dasar Kelas V. Jurnal Penndidikan Dasar, 1(9), 1-11. https://doi.org/doi.org/10.21009/JP D.091.01

Fariyani, Q., Rusilowati, A., \& Sugianto, S. (2017). Four- Tier Diagnostic Test to Identify Misconceptions in Geometrical Optics. Unnes Science Education Journal, 6(3), 8-17.

Gronmo, L. S., Lindquist, M., Arora, A., \& Mullis, I. V. S. (2016). TIMMS 2015 Mathematics Framework. TIMSS 2015 International Results in Mathematics.

Hadi, A. (2019). Peningkatan Hasil Belajar Matematika melalui Strategi Interaktif dengan Menggunakan Metode Pembelajaran Drill pada Siswa Kelas IX MIPA 6 SMA Negeri 16 Makasar. EQUAL Jurnal Ilmiah 
DOI: https://doi.org/10.24127/ajpm.v9i4.3159

Pendidikan Matematika, 2(2), 5361. Retrieved from ejournals.umma.ac.id/index.php/eq uals/article/...

Haji, S., Abdullah, Ilham, M., \& Yumiati. (2017). Mengembangkan Jiwa KewirausahaMahasiswa Melalui Pembelajaran Luar Kelas. Seminar Nasional Pendidikan Nonformal FKIP Universitas Bengkulu, 1(1), 207-212.

Hasyim, Maylita; Kusuma, F. (2019). Analisis high order thinking skill (hots) siswa dalam menyelesaikan soal open ended matematika. FIBONACCIJurnal Pendidikan Matematika Dan Matematika, (1), 55-64.

Hidayah, N. (2016). Menggagas Pendidikan Berwawasan Kewirausahaan di Perguruan Tinggi Islam: Studi Kasus Fakultas Syari'ah dan Ekonomi Islam Iain "SMH" Banten 2014-2015. Islamiconomic: Jurnal Ekonomi Keuangan Dan Bisnis Islam, 7(1), 77-112.

Hidayati, A. U., \& Retnawati, H. (2018). Keefektifan Pendekatan PBL Dan Pendekatan Saintifik Ditinjau dari HOTS dan Karakter. Jurnal Pendidikan Matematika Dan Sains, 6(1), 70-82.

Ichsan, I. Z., Sigit, D. V., \& Miaesyah, M. (2019). Enviromental Learning Based on Higher Order Thinking Skills: A Needs Assessment. International Journal for Educational and Vocational Studies, 1(1), 21-24h. https://doi.org/http://doi.org/10.281 03/ijevs.v1i1.1389

Juwaeriah, S., Muhyani, \& Ikhtiono, G. (2017). Pengaruh model pembelajaran kooperatif tipe jigsaw terhadap motivasi belajar dan hasil belajar siswa pada mata pelajaran matematika. Attadib: Journal of Elementary Education, 1(2), 78-79.

Khotimah, R. P., \& Sari, M. C. P. (2020). Pengembangan Lembar Kerja Peserta Didik Berbasis Higther Order Thingking Skills (HOTS) Menggunakan Konteks Lingkungan. AKSIOMA: Jurnal Program Studi Pendidikan Matematika, 9(4), 761-775. https://doi.org/http;//doi.org/10.241 27/ajpm.v9i3.2909

Khusniati, M. (2012). Pendidikan karakter melalui pembelajaran IPA. Jurnal Pendidikan IPA Indonesia, 1(2), 204-210. https://doi.org/10.15294/jpii.v1i2.2 140

Kurniati, D., Harimukt, R., \& Jamil, N. A. (2016). Kemampuan Berpikir Tingkat Tinggi Siswa Smp Di Kabupaten Jember Dalam Menyelesaikan Soal Berstandar PISA. Jurnal Penelitian Dan Evaluasi Pendidikan, 20(2), 142155. Retrieved from http://journal.uny.ac.id/index.php/j pep

Makarao, M. T., \& Zoelva, H. (2018). Syarikat Islam Dalam Integritas Dunia Pendidikan Dan Kewirausahaan Bagi Kemandirian Umat. Veiritas Jurnal Program Pascasarjana Ilmu Hukum Univesitas As-Syafiiyah, 4(2), 35$57 . \quad$ https://doi.org/DOI: https://doi.org/10.34005/veritas.v4i 2.412

Maryati, S. (2015). Dinamika Pengangguran Terdidik: Tantangan Menuju Bonus Demografi Di Indonesia. Economica, 3(2), 124136.

https://doi.org/10.22202/economic a.2015.v3.i2.249 
Megawati, M., Wardani, A. K., \& Hartatiana, H. (2020). Kemampuan Berpikir Tingkat Tinggi Siswa Smp Dalam Menyelesaikan Soal Matematika Model PISA. Jurnal Pendidikan Matematika, 14(1), 1524.

https://doi.org/10.22342/jpm.14.1. 6815.15-24

Muhyani. (2012). Pengaruh Pengasuhan Orang Tua dan Peran Guru di Sekolah terhadap Kesadaran Beragama dan Kesehatan Mental. (N. Hidayat, Ed.). Jakarta: Direktorat Pendidikan Tinggi Islam, Kementerian Agama RI.

Muhyani. (2019). Metodologi Penelitian. UIKA Press.

Muhyani, \& Dahlia, D. (2015). Pengaruh Model Pembelajaran Kooperatif Tipe Kepala Bernomor Struktur Terhadap Kemandirian Dan Kerja Keras Siswa. Attadib: Journal of Elementary Education, 1(1), 1-16.

OECD. (2019). PISA 2018 Results. OECD Publishing.

Puspendik. (2019). Hasil UNBK. Jakarta. Retrieved from hasilun.puspendik.kemdikbud.go.i d

Putri, I. D. C. K., \& Widodo, S. A. (2018). Hubungan Antara Minat Belajar Matematika, Keaktifan Belajar Siswa, dan Persepsi Siswa Terhadap Prestasi Belajar Matematika Siswa. In Prosiding Sewminar Nasional Etnomatnesia (pp. 721-724). Yogyakarta: Program Studi Pendidikan Matematika Universitas Sarjanawiyata Tamansiswa. Retrieved from jurnal.estjogja.ac.id/index.php/etno matnesia
Ramos, J. L. S., Dolipas, B. B., \& Villamor, B. B. (2013). Higher Order Thinking Skills and Academic Performance in Physics of College Students : A Regression Analysis. International Journal of Innovative Interdisciplinary Research. https://doi.org/ISSN 1839-9053

Rezkillah, I. I., \& Haryanto. (2020). Pengaruh Model Pembelajaran Problem Based Learning Terintegrasi High Order Thinking Skill Terhadap Kemampuan Berpikir Kritis dan Sikap Percaya Diri. Jurnal Pendidikan Sains Indonesia Program Studi Pendidikan IPA Pascasarjana Universitas Syiah Kuala, 8(2), 257268.

https://doi.org/10.24815/jspi.v8i2.1 7322

Riadi, A. (2016). Problem-Based Learning Meningkatkan HigherOrder Thinking Skills Siswa Kelas VIII SMPN 1 Daha Utara Dan SMPN 2 Daha Utara. Math Didactic: Jurnal Pendidikan Matematika. https://doi.org/10.33654/math.v2i3. 44

Sastrawati, E., Rusdi, M., \& Syamsurizal. (2011). Pembelajaran Berbasis Masalah, strategi metakognisi, dan keterampilan berpikir tingkat tinggi siswa. Tekno-Pedagogi, 1(2), 1-14. Retrieved from https://onlinejournal.unja.ac.id/index.php/pedag ogi/article/download/668/595

Siregar, B. P. (2020, September). Jumlah Pengusaha Indonesia Masih Tertinggal dari Singapura. Warta Ekonomi.Co.Id. Retrieved from https://www.wartaekonomi.co.id/re ad204928/jumlah-pengusaha- 
DOI: https://doi.org/10.24127/ajpm.v9i4.3159

indonesia-masih-tertinggal-darisingapura

Suhirman, Yusuf, Muliadi, A., \& Prayodi, S. (2020). The Effect of Problem-Based Learning with Character Emphasis toward Students Higher-Order Thinking Skills and Characters. International Journal of Emerging Technologies in Learning, 15(6), 183-191. https://doi.org/https://doi.org/10.39 91/ijet.v15i06.12061

Supriatna, H. (2017). Pembentukan Kemampuan Literasi Matematika dan Jiwa Kewirausahaan pada Pembelajaran Matematika Model Problem Based Learning Berpendekatan Entrepreneurial Pedagogy. Unnes Journal of Mathematics Education Research, 6(1), 1-10. Retrieved from http://jounal.unnes.ac.id/sju/index. php/ujmer

Sutrisno, Happy, N., \& Susanti, W. (2020). Eksperimentasi Model Discovery Learning Terhadap Prestasi Dan Minat Belajar Matematika Siswa. AKSIOMA: Jurnal Program Studi Pendidikan Matematika, 9(3), 580-590. https://doi.org/https://doi.org/10.24 127/ajpm.v9i3.2804
Syafi'i, A., M , Tri, S. . K. (2018). Study About Student Learning Achievement Aspect and. Jurnal Komunikasi Pendidikan, 2(2), 115123.

Tanujaya, B., Mumu, J., \& Margono, G. (2017). The Relationship between Higher Order Thinking Sklills and Academic Performance of Student in Mathematics Intruction. International Education Studies, 10(11), 78-85. https://doi.org/10.5539/ies.v10n11 p78

Yunitasari, I. (2018). Desain Bahan Ajar Matematika Dengan Pendekatan Metakognitif Berbasis Pemecahan Masalah Pada Pokok Bahasan Bangun Ruang Sisi Datar. Universitas Pasundan scienti. Universitas Pasundan. Retrieved from

http://repository.unpas.ac.id/id/epri $\mathrm{nt} / 40251$ 